\title{
Is $\mathrm{LiFePO}_{4}$ Technology Ready for Internet of Things?
}

\author{
Andre Loechte, Frederik Hoffmann, Christine Krimphove, Gregor Rebel, Peter Gloesekoetter \\ Department of Electrical Engineering and CS, University of Applied Sciences Muenster, Steinfurt, Germany \\ Email: a.loechte@fh-muenster.de
}

Received December 31, 2013; revised January 10, 2014; accepted January 17, 2014

Copyright (C 2014 Andre Loechte et al. This is an open access article distributed under the Creative Commons Attribution License, which permits unrestricted use, distribution, and reproduction in any medium, provided the original work is properly cited. In accordance of the Creative Commons Attribution License all Copyrights (C) 2014 are reserved for SCIRP and the owner of the intellectual property Andre Loechte et al. All Copyright (C) 2014 are guarded by law and by SCIRP as a guardian.

\section{ABSTRACT}

While self-sufficient sensors and actors are about to pave the way for a new computing class, associate Internet of Things applications will highly depend on efficient and reliable storage of electrical energy. Likewise the same is true for electrical based transport systems requiring light weights and high capacities. Recently, novel $\mathrm{LiFePO}_{4}$ based storage cell types with standardized form-factors have become available. These cells tend to be promising in terms of high energy densities, low self-discharge rates and long cycle lives. Anyhow, the aging behavior, maturity, statistical spread and reliability of these new cells have not been analyzed and modeled thoroughly. Therefore, we analyze and compare in this paper the self-discharge behavior, lifetime and reliability of different lithium-based battery cells using a dedicated test bench. We use temperature, voltage, current, and power cycling as acceleration and stress parameters.

\section{KEYWORDS}

\section{Self-Discharge; Degradation; Lithium-Ion; Lithium-FePO ${ }_{4}$; Arrhenius; Lifetime; Aging}

\section{Introduction}

Lithium-based rechargeable battery cells are becoming more and more popular for emerging applications [1]. This is not limited to the new evolving Internet of Things computing class, but also holds true for electrical based transport systems. For instance, numerous applications in the hand-held domain depend on a seamless and reliable energy supply. In terms of gravimetric energy density and coulombic efficiency capacity lithium based battery cells tend to be advantageous in comparison to classic battery concepts. However, the aging behavior, self-discharge, and reliability of these novel devices have not been analyzed and captured thoroughly. In contrast to earlier studies, this paper deals with the wear-out and self-discharge behavior of different types of lithiumbased batteries cells depending on both temperature and charging cycles. The tests were carried out on Tenergy LiIon RCR123A 3.0V $900 \mathrm{mAh}$ rechargeable batteries and Tenergy $\mathrm{LiFePO}_{4}$ RCR123A 3.0V $750 \mathrm{mAh}$ rechargeable batteries [2-4].

\section{Aging and Self-Discharge of Lithium-Based Batteries}

Lithium based batteries consist of one positive and one negative electrode, a separator and an electrolyte. The anode material is graphite/carbon with intercalated lithium. It is chosen because it has a high capacity for lithium. For cathode material the most common one is lithium cobalt dioxide $\left(\mathrm{LiCoO}_{2}\right)$. For newer lithiumbased batteries this is replaced by lithium iron phosphate $(\mathrm{LiFePO})$ because of its lower cost, it is friendlier to the environment and it is safer as it is nontoxic. Furthermore, the upcoming demand cannot be covered by cobalt [5].

During discharge lithium is intercalated into the cathode while during charge it is intercalated into the anode. The reaction equation is shown exemplarily for the $\mathrm{LiFePO}_{4}$ battery:

$$
\begin{gathered}
\text { Anode }: \mathrm{LiC}_{6} \underset{\text { charge }}{\stackrel{\text { Discharge }}{\rightleftarrows}} \mathrm{C}_{6}+\mathrm{Li}^{+}+\mathrm{e}^{-} \\
\text {Cathode }: \mathrm{Li}^{+}+\mathrm{e}^{-}+\mathrm{FePO}_{4} \underset{\text { charge }}{\stackrel{\text { Discharge }}{\rightleftarrows}} \mathrm{LiFePO}_{4}
\end{gathered}
$$

Aging of a lithium-based battery becomes noticeable 
when the internal resistance increases and the capacity of the cell decrease. Due to the capacity decrease the energy supply of the cell also decreases. Factors which influence this aging can be all parts of the cell, such as the electrodes and the electrolyte as well as the separator. The graphite for example which builds the negative electrode sometimes changes its morphology or even breaks. This happens due to mechanical stress such as temperature cycling. Furthermore it is possible that a thin film from lithium salts or lithium carbonates builds up at the boundary between graphite and electrolyte. Due to this the lithium ions are hindered while traveling to the electrode and the internal resistance increases. The effect of morphology can also occur at the positive electrode due to the high potential of the cell. This change in the crystal structure blocks the intercalation of lithium. A consequence of this is capacitance loss. The electrolyte can be contaminated by residual humidity in the cell. Due to this the cell can break. The separator should isolate electrons, but conduct ions. Due to temperature effects the separator abrades. Furthermore oxidation leads to a decrease in porosity which results in a higher internal resistance.

Self-discharge is accelerated by high temperatures. Typically, lithium-ion cells loose $8 \%$ of their capacity during the first month and $2 \%$ in the following months [6]. This self-discharge decreases when the named thin film builds up at the anode as the film consumes the intercalated lithium [7].

\subsection{Charging and Discharging of Batteries}

Rechargeable batteries are limited in terms of charge/ discharge cycles. To determine the lifetime in reasonable time, the batteries are stressed by temperature and continuous charge/discharge cycles. The capacity is automatically tracked by a charging/discharging system and a computer system. Three samples of each battery type were used at three different temperatures. The temperature stress is realized thru thermal chambers with $30^{\circ} \mathrm{C}$, $40^{\circ} \mathrm{C}$ and $50^{\circ} \mathrm{C}$. During the measurements, the batteries were kept at a constant temperature. The batteries were charged with the constant current constant voltage procedure (CCCV) at a charging rate of $1 / 2 \mathrm{C}$. A constant current of $1 / 2 \mathrm{C}$ discharged the batteries to the specified minimum voltage.

\subsection{Self-Discharge of Lithium-Based Batteries}

The self-discharge of batteries was observed at different temperatures. Before starting the self-discharging measurement, the batteries' capacities were determined by two charging/discharging cycles.

The tests were conducted at three different temperatures, namely $30^{\circ} \mathrm{C}, 40^{\circ} \mathrm{C}$ and $50^{\circ} \mathrm{C}$. Each thermal chamber were loaded with 24 fully charged sample cells. The cells were kept in the thermal chamber for different durations. After that, the remaining charge was determined thru the previous mentioned discharging process.

\section{Measurement and Experimental Results}

\subsection{Capacity Degradation over Time}

Each measurement setup includes three batteries to compensate production-related deviations. The arithmetic average of the capacities is plotted to analyze the degradation over time.

Figure 1 shows the capacities over time of the $\mathrm{LiFePO}_{4}$ cells at $30^{\circ} \mathrm{C}, 40^{\circ} \mathrm{C}$ and $50^{\circ} \mathrm{C}$. The capacities decrease slowly and nearly linear. Furthermore it exists only a small dependency of temperature. Nevertheless, the level of the capacities is on a low level compared to the nominal capacity of the battery (750 mAh). Due to a software issue the experiment was paused for 18 days after cycle 300. Although the batteries were not charged in this time, the high temperature in the $50^{\circ} \mathrm{C}$ oven caused a small degradation.

The measured capacities over time of the LiIon batteries at $30^{\circ} \mathrm{C}, 40^{\circ} \mathrm{C}$ and $50^{\circ} \mathrm{C}$ are shown in Figure 2 . The degradation strongly depends on the temperature. While the $30^{\circ} \mathrm{C}$ curve nearly holds the starting level, especially the measured capacities at $50^{\circ} \mathrm{C}$ decrease rapidly over time. Compared to the $\mathrm{LiFePO}_{4}$ cells the capacity of the ion batteries is higher and matches the nominal capacity of $600 \mathrm{mAh}$.

\subsection{Self-Discharge over Time}

As the number of batteries samples per type was limited to 100 , two of them are used per type and per week to determine the self-discharge.

Figure 3 shows the self-discharge of the $\mathrm{LiFePO}_{4}$ batteries at $30^{\circ} \mathrm{C}, 40^{\circ} \mathrm{C}$ and $50^{\circ} \mathrm{C}$. While the measurement at $30^{\circ} \mathrm{C}$ fits well to a power function, the data points of the other measurements vary from week to week.

The measurement points of the LiIon cells at $30^{\circ} \mathrm{C}$, $40^{\circ} \mathrm{C}$ and $50^{\circ} \mathrm{C}$ are plotted in Figure 4. All of them fit to

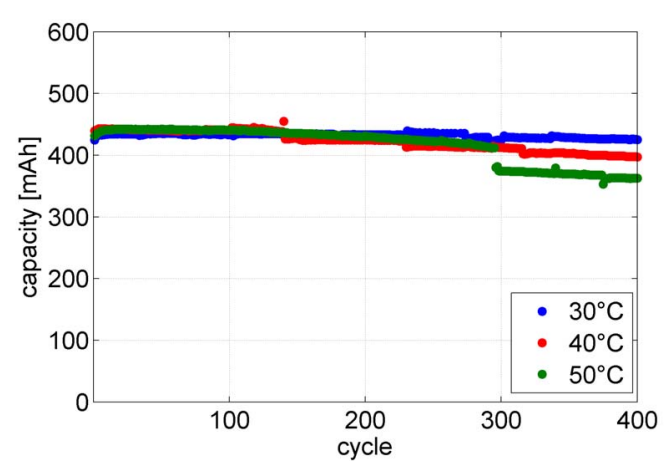

Figure 1. Measured capacity over time of $\mathrm{LiFePO}_{4}$ batteries. 


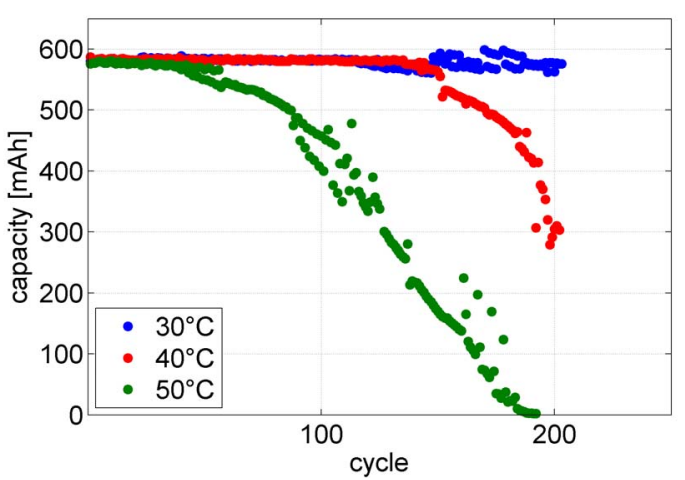

Figure 2. Measured capacity over time of Ion batteries.

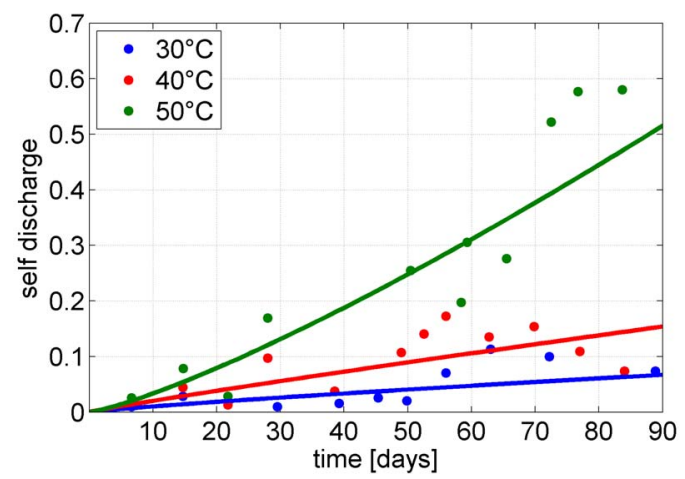

Figure 3. Self discharge $\mathrm{LiFePO}_{4}$.

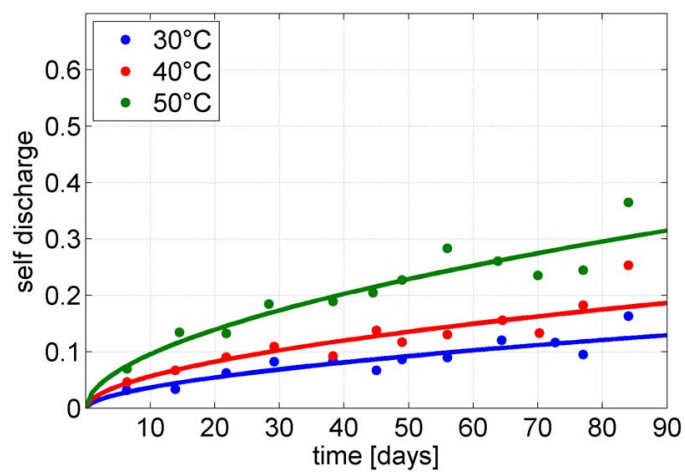

Figure 4. Self-discharge LiIon.

power functions. The difference between the $50^{\circ} \mathrm{C}$ curve and the $40^{\circ} \mathrm{C}$ curve is higher than the difference between the $40^{\circ} \mathrm{C}$ and $30^{\circ} \mathrm{C}$ curve. Nevertheless the discrepancy is smaller than the degradation over time measurement.

Another point is the coulombic efficiency. It describes the ratio between the stored charge and the available charge during the discharge cycle. This value is especially important for energy harvesting applications. The coulombic efficiency at $30^{\circ} \mathrm{C}$ is plotted in Figure 5 .

At the beginning the efficiency of the $\mathrm{LiFePO}_{4}$ batteries is higher. But as the self-discharge rate of the LiIon batteries is smaller than of the $\mathrm{LiFePO}_{4}$ batteries, this situation is reversed after 55 days.

\section{Analysis}

An Arrhenius plot is used to determine the effect of temperature on the cycle life of the batteries. By displaying the logarithm value of the lifetime cycles against the inverse thermodynamic temperature, the dependency of temperature is shown as a straight line. The data-sheets define the cycle life as the number of cycles when the capacity is lower than $70 \%$ compared to the initial capacity. Due to limited measurement time, no test setup reached this limit. Therefore this analysis uses $90 \%$ of the initial capacity as life time limit. Table 1 summarizes the resulting lifetime cycles.

Both cell types did not reached this limit at $30^{\circ} \mathrm{C}$, either. So the measurements at $40^{\circ} \mathrm{C}$ and at $50^{\circ} \mathrm{C}$ are used to create the Arrhenius plot which is shown in Figure 6.

The plot corresponds to the observations mentioned in chapter 2.1 capacity degradation over time. The slope of the LiIon curve is less steep than the curve of the $\mathrm{LiFePO}_{4}$ cells. This indicates that the cycle lifetime of the LiIon batteries is stronger reduced by high temperatures. While

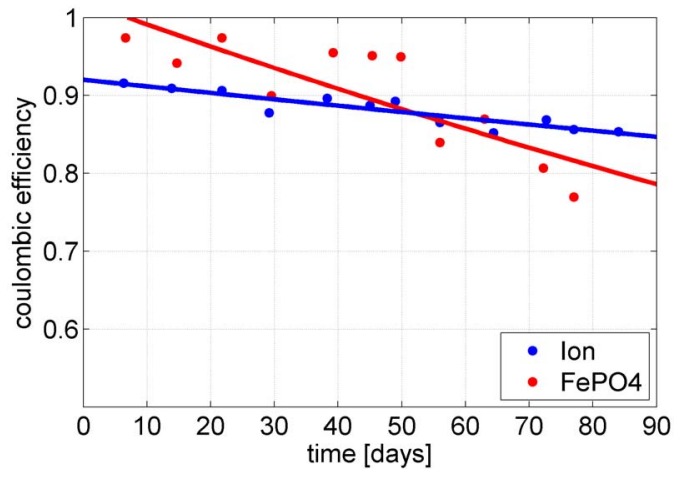

Figure 5. Coulombic efficiencies at $30^{\circ} \mathrm{C}$.

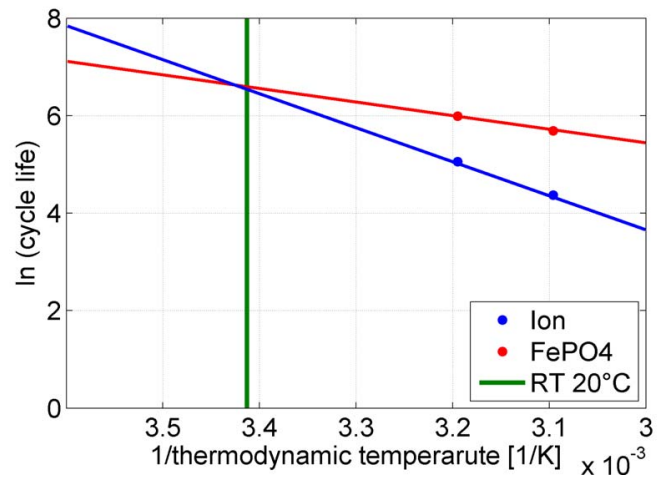

Figure 6. Arrhenius plot.

Table 1. Cycle life.

\begin{tabular}{ccc}
\hline Temp. $\left[{ }^{\circ} \mathrm{C}\right]$ & Cycles LiIon & Cycles $\mathrm{LiFePO}_{4}$ \\
\hline 40 & 157 & 399 \\
50 & 79 & 296
\end{tabular}


the cycle lifetime of both battery types clearly differ at $50^{\circ} \mathrm{C}$, it is nearly identical at room temperature. The expected cycle life times at $20^{\circ} \mathrm{C}$ and $25^{\circ} \mathrm{C}$ are shown in Table 2.

The self-discharge rates of both cell types increase at higher temperature values. Two cell samples per type were taken out of the thermal chamber per week as described in chapter 2. Figure 7 shows the average selfdischarge deviation of two cells belonging to the same sample point at $30^{\circ} \mathrm{C}, 40^{\circ} \mathrm{C}$ and $50^{\circ} \mathrm{C}$. Obviously, the LiIon batteries show less spread. While the deviation of the LiIon samples stays on the same low lever at all temperatures, the deviation of the $\mathrm{LiFePO}_{4}$ cells rises above $14 \%$.

This is critical for applications which use a series connection of multiple battery cells and have a long stand-by time. The deviation of charge may lead to an overcharge or an exhaustive discharge of one of the battery cells that damages the battery precociously.

In the next step the average deviation from the expected value is analyzed. Therefore, the standard deviation is used as an indicator (see Figure 8). The expected values are determined on the basis of the trend lines. Once again the LiIon batteries are more reliable than the $\mathrm{LiFePO}_{4}$ batteries as their self-discharge fits better to the expected values and is therefore the behavior is more predictable.

\section{Conclusion}

Capacity degradation, lifetime and self-discharge rates for LiIon and $\mathrm{LiFePO}_{4}$ samples were analyzed under different ambient conditions. It turned out that LiIon cells seem to be more adequate suited for mobile applications with long stand-by times, since they depend on low and

Table 2. Cycle life at $20^{\circ} \mathrm{C}$ and $25^{\circ} \mathrm{C}$.

\begin{tabular}{ccc}
\hline Battery & Cycles at $20^{\circ} \mathrm{C}$ & Cycles at $25^{\circ} \mathrm{C}$ \\
\hline LiIon & 714 & 480 \\
LiFePO4 & 771 & 648 \\
\hline
\end{tabular}

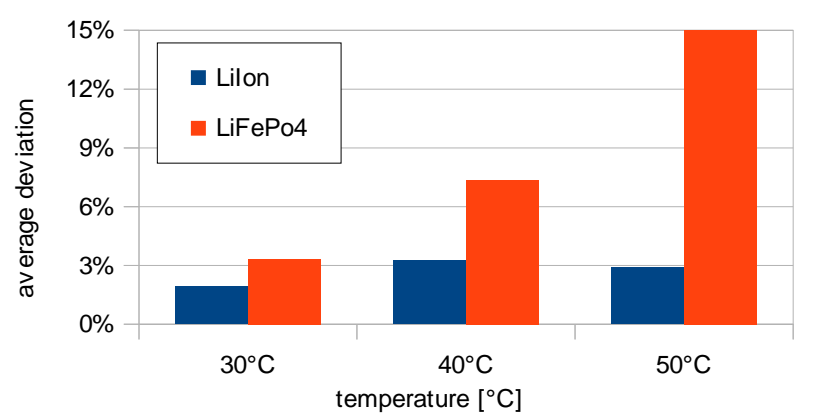

Figure 7. Average self-discharge deviation of two measurements at different temperatures.

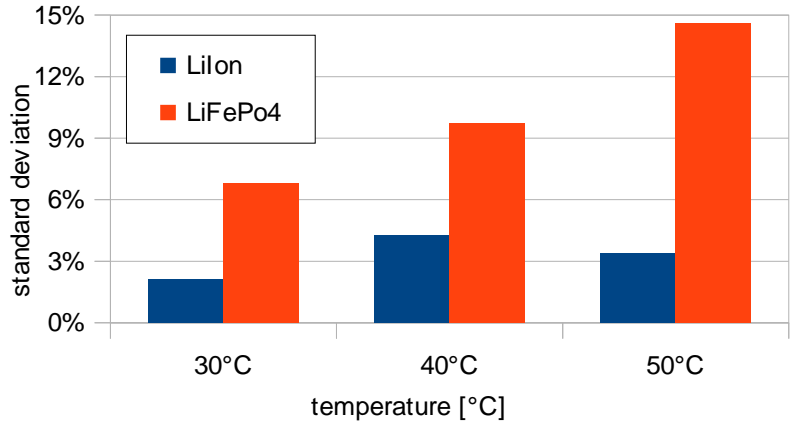

Figure 8. Standard deviation of all self-discharge measurements.

reliable self-discharge rates. $\mathrm{LiFePO}_{4}$ cells tend to be more attractive for applications with a high demand on cycle-lifetime. Anyhow, here the analyzed Tenergy $\mathrm{LiFePO}_{4}$ RCR123A cells show very high spread. This will remain a criterion for exclusion for many commercial applications until deviations come down to the regime of LiIon cells.

\section{Acknowledgements}

This work has been supported by the Wireless Health Monitoring (wihmo) research project of the INTERREG IV A-Program. We would like to thank Dipl.-Ing. Josef Decking for the outstanding support.

\section{REFERENCES}

[1] R. A. Huggins, “Advanced Batteries, Materials Science Aspects,” 2009. http://dx.doi.org/10.1007/978-0-387-76424-5

[2] F. Hoffmann, "Degradation Aware Energy Storage Using Hybrid Capacitors,” 2nd IEEE ENERGYCON Conference \& Exhibition, Florence, 9-12 September 2012, pp. 51-56.

[3] http://www.tenergy.com/30200

[4] http://www.tenergy.com/30201

[5] F. Herb, “Alterungsmechanismen in Lithium-Ionen-Batterien und PEM-Brennstoffzellen und deren Einfluss auf die Eigenschaften von daraus bestehenden Hybrid-Systemen,” Dissertation, Universität Ulm, 2010.

[6] P. R. Roberge, “Self Discharge of Batteries,” 2013. http://corrosion-doctors.org/Batteries/self-compare.htm

[7] C. Wang, X. Zhang, A. Appleby, X. Chen and F. Little, "Self-Discharge of Secondary Lithium-Ion Graphite anodes,” Journal of Power Sources, Vol. 112, No. 1, 2012, pp. 98-112. 